\title{
Suitability analysis for optimum network of agrometeorological stations: A case study of Visayas region, Philippines
}

\author{
LANIE A. ALEJO \\ Isabela State University, Echague, Isabela, Philippines \\ Email:Ihan_1023@yahoo.com
}

\begin{abstract}
An attempt has been made to identify the most suitable sites for agrometeorological stations in Visayas region of Philippines and to determine the barriers in achieving optimum network of stations. Suitability criteria have been used based on the World Meteorological Organization guidelines on establishing agrometeorological stations. The criteria include slope, landuse/landcover, road accessibility, locations from water bodies, coastlines and possible collaborating institutions. Suitability indices for each factor were developed. A geographic information system (GIS) modeling and mapping framework has been presented to serve as a guide to a cost-effective augmented network of agrometeorological stations. The technique can also be adapted to site the best locations for agrometeorological stations in other areas in the Philippines and in other countries. There are 11 suitable stations identified which is 94 per cent less than the optimum number of stations in the study area. Based on the study, the barriers in achieving the optimum number of stations were the unavailability of host institutions, water bodies, and inadequate road infrastructures.In archipelagic and developing countries, funding and policymaking is a challenge in addressing these barriers.
\end{abstract}

Keywords: Agrometeorological station; suitability mapping; GIS

Agrometeorological stations play a significant role in the successful implementation of various research and development programs and for sustainable crop production (Powell and Reinhard 2016). Climate data inputs are always considered as a source of uncertainties in many climaterelated studies (Hamann and Wang 2005). Numerous research papers, especially from the developing countries, have cited inadequacies of weather data that can represent the climate in their areas (Arsenault et al. 2014; Palao et al. 2013). Thereby, resorting to an available agrometeorological station, which are kilometers away from their study areas and some used generated data from climate models and satellites (Fuka et al. 2013). Lack of agrometeorological stations has always been a dilemma to scientist and researchers that hinders better analysis of their data and an issue concerning the accuracy of their results (Vuille et al. 2008).Unsuitable siting of manned weather stations is one of the reasons of inaccuracies in weather data (Gubler et al. 2017). Being permanent structures entails agrometeorological stations to be a source of long-term weather data. They have longer years of observation, which are commonly used in agricultural planning, crop modeling, groundwater modeling, and watershed modeling, among others(Brooks et al.2011).

There are many techniques including manual, ocular, modeling and mathematical methods for identifying suitable sites (Arsenault et al. 2014). Geographic Information System (GIS) technology has been abundantly used for assessing the suitability of crops, small-scale irrigation systems, among others (Singh and Patel 2017). Yildirim et al. (2016) also used GIS to identify the most suitable location for automatic weather stations for the purpose of policy making for natural disasters risk reduction in Turkey. Presently, there are no published studies demonstrating suitability analyses of the best location for agrometeorological weather stations including the identification of barriers that hinders optimum network of stations. In addition, the WMO criteria are very general in its current form that it does not explicitly give the values for each suitability factors.

In this regard, this paper presents a technique and the indices for assessing the most suitable sites for agrometeorological weather monitoring stations using GIS. Moreover, the factors that impede the optimum number of agrometeorological stations were identified. The Visayas is a part of the country, that is frequently struck by strong typhoons which stresses their needs for more permanent weather stations. Hence, the Visayas group of islands was considered as a case study area. 


\section{MATERIAL AND METHODS}

\section{Site description}

The Visayas region is one of the 3 main group of islands in the Philippines. The Visayas has only 16 operational weather stations, five of which are agrometeorological and the rest are synoptics. It is bounded by Luzon at its northern side, Mindanao at its southern part, Pacific Ocean at the east and west Philippine Sea. Based on the WMO recommended weather station density, Visayas should have at least 184 weather stations, which is far from the current established synoptic and agrometeorological stations. Synoptic stations can also be used for research and agricultural production. Hence, there is a need for permanent agrometeorological station augmentation in the Visayas group of islands.

There are many automatic weather stations (AWS) in the islands. However, there are no available database integration systems for these networks. Data measurement standardization is an issue in AWSs systems. Also, most of these units are not functioning as manifested by the unavailability of current data from the corresponding websites. More AWSs that are project-based and privately owned with information difficult to access were not included in the map.There are many technical challenges in implementing AWSs for weather monitoring purposes identified by (Ciach and Ciach 2003; Lazzara et al. 2012; Plummer et al. 2003; Tokay et al. 2010). Due to these, AWSs were not included in the existing weather station for suitability analyses.

\section{Data and criteria}

To ensure cost-effective siting of agrometeorological stations, criteria was recommended by the World Meteorological Organization were used (WMO2010). These general criteria were given values and were used as indices for suitability. The WMO guidelines for setting up an agrometeorological station are generally flat topography, crop production areas should be represented, accessible, far from lakes and water bodies, inside an institution, and it should have at least 1,980sqm of land area. Based on these, the suitability criteria are set in Table 1 . The values out of the ranges for suitability criteria are considered unsuitable for agrometeorological stations. All these factors should be suitably present in the final identified proposed sites.

The data inputs were sourced out from various agencies and websites. The digital elevation model used has 30 meters by 30 meters resolution,Landuse/Landcover (LULC) and the location of possible host institutions were provided by the National Mapping and Resource Information Authority (NAMRIA). The roads and coastlines were downloaded from the Open street map and verified in the Google Earth. The Philippine Atmospheric, Geophysical and Astronomical Services Administration (PAGASA) provided the status and locations of existing weather stations.

\section{Suitability mapping}

Geographic information system (GIS) was used as a tool to facilitate the suitability mapping. The suitability mapping technique used was binary which involves setting the suitable in each factor as 1 and the non-suitable as 0.Fig. 1 provides the GIS mapping framework for ease of replication. GIS tools used, the input data needed and the outputs for each steps are also shown. This framework can also be replicated in the GIS model builder for fast and easy spatial simulation. The importance of fast and easy way that GIS technology offers to determine the suitability of weather stations was reported by Yildirim et al. (2016) when they identified the best locations for automatic weather stations (AWSs) for disaster prevention in Trabzon, Turkey. However, AWSs do not have exactly the same set of suitability factors with agrometeorological stations, which makes its basic difference from the present study.Also, Turkey most likely do not have factor constraints, especially financial, which does not impede implementation of the maximum number of suitable stations. For an archipelagic and third world country, optimizing the set of suitability factors according to resources is very important to ensure maximum use of what is available.

\section{Optimization of network of station}

To determine the optimum number of agrometeorological stations depending on the given factors, a sensitivity analysis on the suitability factors was conducted. One factor was added at a time from the minimum set of factors. Slope, LULC, $<1,980 \mathrm{~m}^{2}$ area, existing permanent weather stations were taken as the set of minimum factors. These factors were considered important since they are uncontrollable physical factors. Others were deemed manageable depending on the available financial resources of the country. The effect of each manageable factors to the optimum network of stations was also estimated in this step.

\section{RESULTS AND DISCUSSIONS}

There are 11 synoptic stations, 5 agrometeorological stations and 2 cooperative climatological stations in the Visayas (Fig. 2). To avoid replicating these stations, 


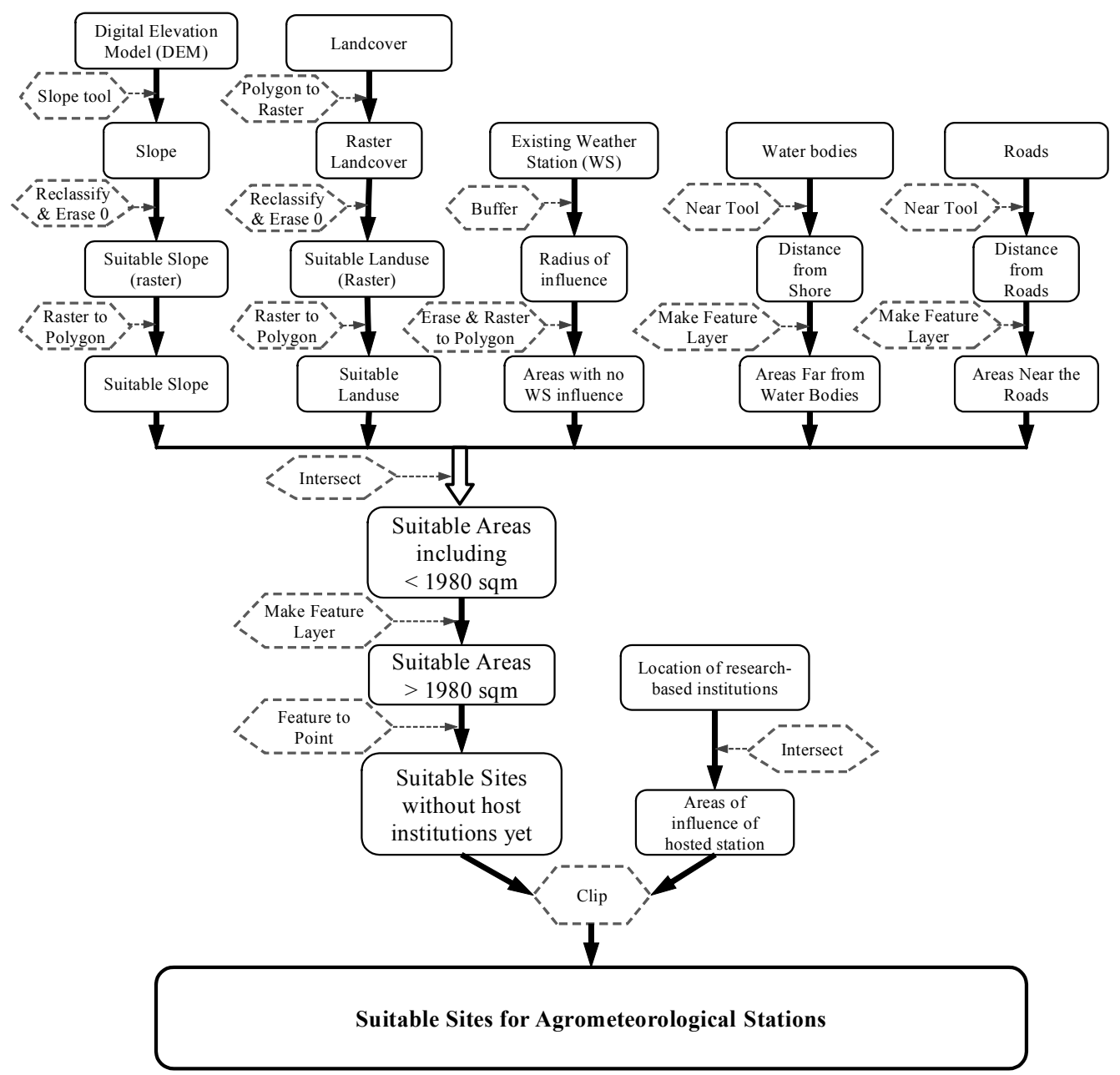

Fig.1: GIS mapping and modeling framework

Table 1: Suitability criteria for weather stations

\begin{tabular}{|c|c|c|}
\hline Factor & Suitability Criteria & Data needed \\
\hline Slope & $0-3 \%$ & DEM \\
\hline Landuse & $\begin{array}{l}\text { Cultivated, production areas, } \\
\text { grasslands }\end{array}$ & Landuse/ Landcover (LULC) \\
\hline Accessibility & At least $500 \mathrm{~m}$ from the road buffer & Roads \\
\hline $\begin{array}{l}\text { Location of existing stations } \\
\text { (Synoptic and agro-meteorological) }\end{array}$ & $\begin{array}{l}\text { Areas outside its } 9 \mathrm{~km} \text { radius of } \\
\text { influence (based on the WMO set } \\
\text { density, } 100-300 \mathrm{~km}^{2} \text { ) }\end{array}$ & Existing weather stations \\
\hline Water bodies (Lakes \& Coastline) & Outside $10 \mathrm{~km}$ buffer & LULC\& coastline \\
\hline Availability of host institution & Inside $9 \mathrm{~km}$ radius & $\begin{array}{l}\text { Locations of research-based } \\
\text { government institutions }\end{array}$ \\
\hline
\end{tabular}

restrictions inside its radius of influence are imposed. The computations provided a $9 \mathrm{~km}$ radius of influence of each existing station. This was basedon the density of 100-300 $\mathrm{km}^{2}$ per weather station WMO guideline. The upper limit was considered in the computation of radius of influence. Most of the synoptic stations are located near the coastlines. They are mainly used for weather and typhoon track forecasting.

\section{Suitable slope and LULC}

The suitable slopes of 0-3 per cent were considered generally flat based on the slope category of Bureau of Soil and Water Management (BSWM). Slope map was derived 


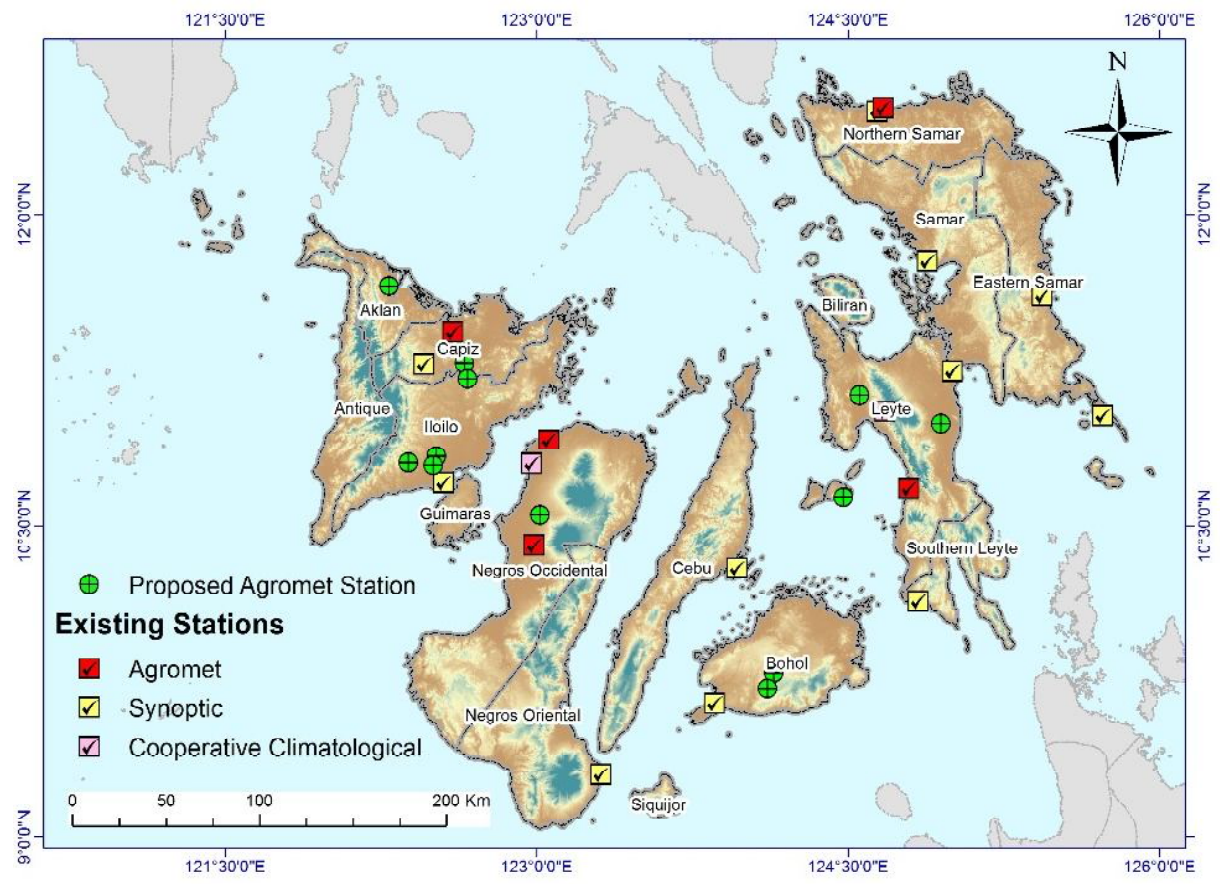

Fig.2: Locations of proposed weather stations

Table 2: Reduction of selected suitable sites as affected by factors

\begin{tabular}{lcc}
\hline Suitability factors & No. of proposed sites & Per centreduction \\
\hline Slope, LULC, $<1,980 \mathrm{~m}^{2}$ area, Existing WS & 713 & - \\
Slope, LULC, $<1,980 \mathrm{~m}^{2}$ area, Existing WS, Institutions & 162 & 340 \\
Slope, LULC, $<1,980 \mathrm{~m}^{2}$ area, Existing WS, Institutions, Coastline & 38 & 326 \\
Slope, LULC, $<1,980 \mathrm{~m}^{2}$ area, Existing WS, Institutions, Coastline, Roads & 12 & 217 \\
\hline
\end{tabular}

from the $30 \mathrm{~m} \times 30 \mathrm{~m}$ resolution digital elevation model (DEM) data. Results showed that there are about 342, 000 ha of flat areas in the Visayas. The flat areas are only 6 per cent of the total area.

Based on the generated map, there are about 4.4 million hectares crop production areas in the Visayas. These areas varied from cultivated with cereals and sugar crops to cropland mixed with plantations and cultivated area mixed with grasslands. Also, coconut plantations and other plantations are planted in about 200,000 ha of land mass. Except for the plantations, cultivated areas were considered suitable for the proposed weather stations. Plantations are composed of trees, which can be difficult to manage to allow open grounds for an agromet stations.

\section{Restrictions and identified suitable sites}

Existing weather stations have a radius of influence of $9 \mathrm{~km}$ based on the recommended density of $100-300 \mathrm{~km}^{2}$. Coastlines were buffered to $10 \mathrm{~km}$ to avoid the microclimate and strong winds from the east coast. The buffered areas from the existing weather stations and coastlines are restricted to establishing weather stations. The recommended area of agrometeorological stations is $55 \mathrm{~m} \mathrm{x} 36 \mathrm{~m}$ or $1,980 \mathrm{~m}^{2}$. The areas less than this were eliminated from the suitable areas identified.

Results showed that if all suitability factors are included in the analysis, there are only 12 suitable sites for weather stations to augment the existing weather stations in the Visayas (Fig.2).The present study used the GIS technology applied in siting agrometeorological stations that are manual type of weather station but considered semipermanent weather monitoring systems. More than the technology itself, the indices in numerical form should be established as the basis for replicating the study. As such, this study presented the suitability indices for siting the most suitable places for agrometeorological stations in table form for quick reference. Although the cost of establishing agromet stations is higher than AWSs, agrometeorological stations have been proven to provide long-term weather data for primarily for agricultural research and secondary for 
other purposes. Long-term weather data are imperative in running various modeling platforms such as those for crop simulation, watershed, flooding, drought and climate among others (Dorji et al.2017; Tongson et al. 2017). Also, inadequate long-term weather data are cited to cause unreliable weather trend analyses (Hunziker et al. 2017). This study provided a GIS modeling framework as a reference for other practitioners with the same purpose for better agricultural research results, weather forecasting, disaster prevention and simulation modeling, among others. With the framework, they can easily build the same using a GIS model builder.

\section{Optimum network of stations}

Availability of collaborating institutions, restriction near coastlines and accessibility were the most restricting factors, which substantially reduced the number of suitable sites for weather stations (Table 2). There can be 713 possible sites suitable for agromet stations if the only considered factors are the slope, LULC, areas with less than 1,980 $\mathrm{m}^{2}$ and existing weather. With the addition of institutions where stations should be installed, possible sites would be greatly reduced to only 162 . Furthermore, with the ocean as a water body that should be avoided, a 10-km buffer would decrease sites to only 38 stations. Finally, when accessibility is included, there can only be 12 possible sites for agromet stations in the region. The distance of the identified suitable sites for agromet stations from the selected host institutions ranged from $0.38 \mathrm{~km}$ to $8 \mathrm{~km}$. There are 11 collaborating institutions identified. Two of the suitable sites shared one of the host institutions thereby further reducing the number of suitable sites to only 11 stations. Quantified reductions in suitable agromet stations with the addition of suitability factors was presented to provide an idea of the impact of some of the criterion. With the Slope, $\mathrm{LULC},<1,980 \mathrm{~m}^{2}$ area and existing WS as the base criteria, there can be many suitable areas for agrometeorological stations in the case study area. However, this is greatly reduced by the unavailability of host institutions where these stations can be installed. The WMO has explicitly expressed the importance of a research institution that will permanently maintain agromet stations. The Philippines, being an archipelago and Visayas composed of groups of islands, water bodies, especially the oceans, additionally reduced the suitable places for agroment stations.However, many permanent weather stations in the country are located near coastlines. If this factor would be strictly included, it will cause 326 per cent reduction of optimum number of agrometeorological stations in the study area. Availability of access roads also significantly reduced the number of suitable sites. Since there are limitations on access roads in some areas, 26 stations were eliminated from the number of suitable stations. Therefore, in archipelagic and developing countries, the ultimate barriers to the optimum number of agrometeorological stations are the unavailable host institutions, water bodies, and insufficient road infrastructures. The optimum number of agromet stations in the study site should at least be 184 but this study only identified 11 suitable sites using GIS. However, if funds are available for roads and institutions, there can be enough suitable sites for agrometeorological stations in the area. Fortunately, funding and policymaking can possibly address these barriers.

\section{CONCLUSION}

This paper presented a technique on siting the best location for a weather station, the quantitative values for the WMO criteria and the barriers to optimum number of suitably sited stations. With the indices laid out, a cost-effective suitability analysis for the agrometeorological station was made fast and easy coupled with the use of the GIS technology.Unavailability of host institutions, water bodies, and inadequate road infrastructures are the barriers for an optimum number of agrometeorological stations in most archipelagic and developing countries.Funding and policymaking in line with building more road infrastructures and host institutions can address these barriers.

\section{ACKNOWLEDGMENTS}

The author would like to thank the agencies mentioned in this article, which generously shared their data. The Department of Science and Technology, Engineering Research and Development for Technology (DOST-ERDT) supported this work.

\section{REFERENCES}

Arsenault, Richard, François Brissette, Richard Arsenault, and François Brissette. (2014). Determining the Optimal Spatial Distribution of Weather Station Networks for Hydrological Modeling Purposes Using RCM Datasets: An Experimental Approach.J. Hydrometeorol., 15(1):517-26.

Brooks, M. S., Sims,A. P., Frazier, A. N., Boyles,R. P., Syed,A., Raman, S.(2011). Climate-Based Decision Support Tools for Agriculture. in "Challenges and Opportunities in Agrometeorology.” Springer. Pp. 245-56. 
Ciach, Grzegorz J. and Grzegorz J. Ciach. (2003). Local Random Errors in Tipping-Bucket Rain Gauge Measurements. $J$. Atmos. Ocean. Technol., 20(5):752-59.

Dorji, Singay, Srikantha Herath and Binaya Mishra (2017). Future Climate of Colombo Downscaled with SDSMNeural Network.Climate, 5(1):24.

Fuka, Daniel R. Walter, M.T., MacAlister, C., Degaetano, A.T., Steenhuis, T.S. and Easton, Z.M. (2013). Using the Climate Forecast System Reanalysis as Weather Input Data for Watershed Models. Hydrol. Proces, 28(22):5613-23.

Gubler, S., Hunziker,S., Begert, M., Croci Maspoli, M., Konzelmann, T., Brönnimann,S., Schwierz,C., Oria, C. and Rosas, G. (2017). The Influence of Station Density on Climate Data Homogenization. Int. J. Climatol. 37(13):4670-83.

Hamann, A. and T. L. Wang. (2005). Models ofClimatic Normals for Genecology and Climate Change Studies in British Columbia. Agric. For. Meteorol., 128(3-4):211-21.

Hunziker, S., Gubler, S., Calle,J., Moreno, I., Andrade, M., Velarde, F., Ticona, L., Carrasco, G., Castellón, Y., Clara Oria, Croci Maspoli, M., Konzelmann, T., Rohrer, M., and Brönnimann, S. (2017). Identifying, Attributing, and Overcoming Common Data Quality Issues of Manned Station Observations. Int. J. Climatol., 37(11):413145 .

Lazzara, M. A., Weidner, G. A.,Keller,L. M., Thom, J. E. and Cassano, John J. (2012). Antarctic Automatic Weather Station Program: 30 Years of Polar Observation. Bull. Am. Meteorol. Soc., 93(10):1519-37.

Palao, Leo Kris M., Moises M. Dorado, Kharmina PaolaA. Anit and Rodel D. Lasco (2013). Using the Soil and Water
Assessment Tool(SWAT) to Assess Material Transfer in the Layawan Watershed, Mindanao, Philippines and Its Implications on Payment for Ecosystem Services. $J$. Sustain. Dev., 6(6):p73.

Plummer, N., T.Allsopp, and J. A. Lopez. (2003). “Guidelines on Climate Observations Networks and Systems". WCDMP No 5. World Meteorological Organization, Geneva, Switzerland.

Powell, J. P. and S. Reinhard(2016). Measuring the Effects of Extreme Weather Events on Yields.Weather Clim. Extrem., 12:69-79.

Singh, Jyoti and Patel,N. R. (2017). Assessment of Agroclimatic Suitability of Apple Orchards in Himachal Pradesh under Changing Climate. J. Agrometeorol., 19(2):110-13.

Tokay, A., Bashor, P.G. and McDowel, V.L.(2010). Comparison of Rain Gauge Measurements in the Mid-Atlantic Region. J. Hydrometeorol., 11(2):553-65.

Tongson, Edgardo E., LanieA. Alejo and Orlando F. Balderama (2017). Simulating Impacts of El Niño and Climate Change on Corn Yield in Isabela, Philippines.Clim. Disaster Dev. J., 2(1):29-39.

Vuille, M.,Francou, B., Wagnon, P., Juen, I., Kaser, G., Mark,B G. and Bradley, R. S. (2008). Climate Change and Tropical Andean Glaciers: Past, Present and Future. Earth-Science Rev. 89(3-4):79-96.

World Meteorological Organization (2010). "Guide to Agricultural Meteorological Practices". $2010^{\text {th }} \mathrm{ed}$.

Yildirim, Volkan, Recep Nisanci, Ebru Husniye Colak and Okan Yildiz (2016). A GIS-Based Siting Technique for Automatic Weather Stations in Trabzon, Turkey. Weather 71(2):43-49. 